REVISTA DE DERECHO UNED, núm. 1, 2006

\title{
LA CAUSA SÉPTIMA DE INDIGNIDAD SUCESORA: UNA MEDIDA DE PROTECCIÓN JURÍDICA PARA PERSONAS DISCAPACITADAS
}

\author{
CARMEN HernáNdeZ IbÁÑEZ
}

Sumario: I. CONSIDERACIONES PREVIAS.-Incapacidad absoluta, por inexistencia de persona, e incapacidad relativa para suceder.-Relaciones entre incapacidad e indignidad para suceder.- Sucinta referencia a los antecedentes históricos de la indignidad sucesoria-Definición de indignidad.-Fundamento de ésta.-II. ANÁLISIS ESTRUCTURAL DE LA CAUSA NÚMERO SÉPTIMA DEL ARTÍ́CULO 756 DEL CÓDIGO CIVIL. II.1. Antecedentes II.2. Ámbito de aplicación personal. II.3 Clases de sucesión en las que se aplica II.4. Falta de prestación al causante por parte del causahabiente de las atenciones debidas. II.5. ¿Sobrepasan las personas obligadas a prestar alimentos a los alimentantes mencionados en el artículo 143 del Código civil?.-III. ¿ESTA CAUSA DE INDIGNIDAD ES TAMBIÉN CAUSA DE DESHEREDACIÓN?-IV. CONCLUSIÓN.

\section{CONSIDERACIONES PREVIAS.}

Las causas de indignidad para suceder aparecen reguladas en el artículo 756 del Código civil ${ }^{1}$, ubicado en el Libro III, Título III, Capítulo II, Sección $1^{a}$, bajo la rubrica «De la capacidad para suceder

1 Aunque sea este el precepto que de forma expresa determina quienes son incapaces para suceder por causa de indignidad, la doctrina ha llamado también la atención sobre la necesidad de tener en cuenta las causas contempladas en el artículo 713 $\mathrm{Cc}$; incluyendo asimismo en este ámbito Lacruz y Sancho el contenido, en lo que al respecto concierne, del artículo $111 \mathrm{del}$ mismo texto legal. Sin embargo, a juicio de Mena-Bernal el legislador en ningún momento quiso otorgar a la pena contemplada 
por testamento y sin él». Sin embargo, con carácter previo el 745 , del mismo texto legal y segundo de la mencionada Sección, declara incapaces para suceder, en todo caso, tanto a las criaturas abortivas como a las asociaciones o corporaciones no permitidas por la Ley. Al lado de esta incapacidad absoluta, erga omnes, de quienes no llegan a alcanzar el presupuesto básico, normativamente necesario, de ser persona física o jurídica, por ausencia de los requisitos legalmente exigibles al respecto; los artículos 752 a 754 contemplan diversas causas de incapacidad relativa para suceder, recayentes en determinadas personas por razón de haber sido, en los términos concretos que en ellos se contemplan, confesor, notario, tutor o curador del testador. Se trata obviamente de evitar que estas personas puedan interferir en el proceso motivador de la decisión testamentaria inclinándola en favor suyo. De ahí pues su incapacidad para suceder a ese testador en concreto con el que aparecen vinculados, pero no a todos lo restantes posibles e hipotéticos testadores en los que esté ausente tal vinculación]. Lo que posibilita hablar de una incapacidad intuitu personae.

Pero en realidad en los supuestos del artículo 745 más que de incapacidad habría acaso que hablar de imposibilidad para suceder por inexistencia de la persona pues, como observa HERNÁNDEZ GIL², criticando la terminología del precepto: «En los casos en que falten los presupuestos necesarios para poder apreciar la existencia de persona... debe hablarse de inexistencia de sucesor mejor que de incapacidad para suceder. Sin embargo, el Código civil califica los supuestos de inexistencia como de incapacidad... técnicamente no hay incapacidades absolutas para suceder porque la incapacidad supone la inexistencia de persona. Existen, sí, las denominadas incapacidades relativas que entrañan una merma en la capacidad, afectan siempre a la persona. Incapacidad relativa en materia sucesoria sería la

en el artículo 713 el carácter de indigna ni tampoco, por consiguiente, fue su intención elevarla a causa de indignidad. Vid. MENA-BERNAL ESCOBAR, Maria José, La indignidad para suceder, Edit. Tirant lo Blanch, 1995, pp.58 y 61

En lo que a comentarios sobre el artículo 756 se refiere, puede verse, entre otros: MANRESA Y NAVARRO, José Maria, Comentarios al Código Civil. T. VI. Vol. I, Octava Edición revisada y puesta al día por Martinez Calcerrada, Luis,Edit. Reus, 1973; ALBALADEJO GARCIA, Manuel, Comentarios al Código civil y Compilaciones forales. T.X Vol. $1^{\circ}$ ((Dirigidos por M. Albaladejo), Edit. Edersa, 1987, pp196-238; CASTRO GARCIA, Jaime de, Código Civil. Doctrina y Jurisprudencia. T.III. ( Dirigidos por J.L. Albacar) Edit. Trivium, 1991. pp.459-465; DIAZ ALABART, Silvia Comentario del Código Civil. T.I. Ministerio de Justicia, 1991, pp.1863-1865.

2 HERNÁNDEZ GIL, Felix, La indignidad sucesoria: naturaleza jurídica declaración judicial y efectos, Revista de Derecho Privado, 1961, p.468. 
privación, para ciertas personas, de la posibilidad de suceder a cualquier persona; cuando la privación del derecho de suceder se concreta respecto a determinadas personas no debería hablarse de incapacidad relativa, sino más bien de prohibición o de incompatibilidad para suceder.»

La relación entre indignidad e incapacidad no suscita opiniones del todo concordantes en la doctrina. Atendiendo a la literalidad de la expresión «son incapaces para suceder por causa de indignidad»que emplea el Código civil en su artículo 756, se ha dicho que estamos en presencia de una especie de incapacidad. En esta línea de pensamiento, los primeros comentaristas del Código civil aproximaron la indignidad a la incapacidad por considerar que el hecho que motiva la prohibición de suceder en la primera es una verdadera forma de incapacidad, idéntica a la establecida por otros motivos para el sacerdote, tutor, curador o notario. Y de esta opinión participan también quienes modernamente sostienen que la indignidad es una causa de incapacidad relativa que impide la delación. Otros, si bien asimilan ambas figuras, entienden sin embargo que se produce una delación, aunque claudicante, en favor del incapaz o del indigno, hasta que una ulterior declaración judicial de indignidad o de incapacidad la destruya con efectos retroactivos o bien se consolide por el transcurso del plazo de impugnación sin que se haya utilizado la acción correspondiente, conforme a la máxima indignus potest cape$r$, sed non potest retinere.

Por otra parte se ha observado que, a diferencia de la indignidad, las incapacidades relativas no pueden ser removidas por el testador. De manera tal que las disposiciones testamentarias efectuadas vulnerando estas últimas son nulas de pleno derecho, y los designados que lleguen a posesionarse de los bienes sólo podrán adquirir definitivamente el dominio mediante la usucapión por carecer de título hereditario idóneo. Se ha señalado asimismo ${ }^{3}$ que este problema carece de interés práctico, pues aunque fuese verdad que al indigno le asista la delación ésta se entenderá retroactivamente destruida si prospera la impugnación por indignidad sucesoria; y de no ser así es claro que, una vez transcurrido el plazo para la sucesión del indigno, éste conservará los bienes adquiridos por usucapión. Esta opinión prescinde sin embargo del concreto disfrute de los bienes por parte del indigno que en ocasiones puede ser relevante y no siempre susceptible de ser indemnizado.

\footnotetext{
3 ALBALEDEJO GARCIA, Manuel, Ob. cit. p.198.
} 
De manera análoga en cierto modo a la doctrina científica, la emanada del Tribunal Supremo en sentencia de 11 de febrero de 1946, y «sin pretensiones de identificar en absoluto las causas de incapacidad con las de indignidad para suceder en testamento o abintestato", observa "en ellas un marcado nexo... en cuanto unas y otras tienden a impedir que el heredero entre en posesión de la herencia.» La indignidad «constituye por si sola - al decir de la sentencia del Tribunal Supremo de 7 de marzo de 1980 - un motivo de incapacidad relativa para suceder, haya o no desheredación, de no mediar la remisión expresa o tácita a que se refiere el artículo 757.» ${ }^{4}$

Los antecedentes históricos de la indignidad sucesoria hay que buscarlos, una vez más, en el Derecho romano, donde ciertas personas no carentes de testamenti factio passiva $\mathrm{y}$, por tanto, capaces de suceder tanto a título universal como singular, se veían sin embargo afectadas para conservar lo adquirido a título de herencia o legado, por causa de su reprobable conducta con el difunto; quedando aquéllos, según los casos, en provecho del Fisco, del coheredero, del gravado con la entrega o del heredero legitimo. Las Partidas siguieron esta doctrina, señalando que los efectos de la pérdida de la herencia o de la manda "e develas aver al Rey». En el Proyecto de García Goyena de 1851 las causas de indignidad figuran en el artículo 617; en el Anteproyecto de Código civil de 1882 en el artículo 754, quedando finalmente recogidas, con algunas variaciones respecto a los dos textos anteriores, en el artículo 756 del texto de $1889^{5}$.

La indignidad sucesoria puede ser definida, siguiendo a JORDANO FRAGA ${ }^{6}$, como «privación automática, ex lege, al ofensor, salvo rehabilitación concedida por el causante ofendido, y en virtud de la comisión por aquél de cualquiera de los hechos legalmente tipificados a tal fin, de todo derecho sucesorio en la sucesión abierta de tal causante.» Considerándose indigno " al que, teniendo capacidad para serlo (heredero), no puede, sin embargo, percibir la herencia por actos propios y personales, que no le hacen merecedor para suceder al causante. ${ }^{7}$

${ }^{4}$ CASTRO GARCIA, Jaime de, Ob. cit. pp. 460-461. Vid. HERNÁNDEZ GIL, Felix, La indignidad sucesoria: naturaleza jurídica declaración judicial y efectos, Revista de Derecho Privado, 1961. pp.472-478; MENA- BERNAL ESCOBAR, M $^{a}$ José, Ob. cit. pp.36-43; PÉREZ DE VARGAS MUÑOZ, José, La indignidad sucesoria en el Código civil español, Edit. MacGraw-Hill, 1997, pp.30-45.

5 Vid. PÉREZ DE VARGAS MUÑOZ, José, La indignidad sucesoria en el Código civil español, pp.1-17.

6 JORDANO FRAGA, Francisco, Indignidad sucesoria y desheredación, Edit. Comares, 2004, p.1.

7 MANRESA Y NAVARRO, José Maria, Ob. cit. p.79. 
Existe coincidencia en la doctrina ${ }^{8}$ en que el incurso en indignidad queda excluido de la sucesión del causante, al que ofendió con su acto indigno, tanto si la sucesión es testada como intestada y lo mismo si la recibe a título de heredero o de legatario. «Lo que no especifica el artículo -observa ALBALADEJO ${ }^{2}$ - es que solo sea indigno del causante ofendido. Pero, sin embargo, es seguro, pues la indignidad se construye por nuestra ley como ineptitud relativa, es decir, orientada a excluir al indigno solo de la sucesión de la persona agraviada por él, no como exclusión de heredar de cualquiera, porque su acto merezca el castigo de que no pueda suceder a nadie."

La generalidad de la doctrina suele atribuir a la indignidad sucesoria un doble fundamento subjetivo-objetivo ${ }^{10}$ : basado el primero en la suposición de que sí el causante hubiera previsto el hecho del indigno, hubiera procedido el mismo a excluirlo de la herencia, y el segundo en consideraciones de moral social que obligan al legislador a privar de la herencia a quienes se han hecho indignos de ella, según el común sentir. Exponente de esta tendencia podría ser, por ejemplo, VALVERDE ${ }^{11}$, para quien: " La indignidad es una exclusión de la sucesión pronunciada a título de pena o privación de derechos contra el heredero culpable en relación al causante de la herencia, y por tanto, tiene un doble fundamento: de una parte la suposición de que sí el difunto hubiere manifestado su voluntad, lo hubiera hecho en contra del indigno, y por otra, razones de moralidad impulsan al legislador a privar de la herencia a aquellas personas que han cometido tales hechos en contra del difunto, que a la conciencia pública o social repugnaría que fuera el autor de ellos sucesor de la victima.»

8 Vid. entre otros autores: MANRESA Y NAVARRO, José Maria, $O b$. cit. p.82; VALVERDE Y VALVERDE, Calixto, Tratado de Derecho Civil Español. T.V: Parte especial. Derecho de Sucesión Mortis Causa, Valladolid 1939, p.443; ALBALADEJO GARCIA, Manuel Ob. cit. p. 205; CASTAN TOBEÑAS, José, Derecho Civil Español, Común y Foral. T. VI. Derecho de Sucesiones. Vol. Segundo, Edit. Reus, 1975, p.46: LACRUZ BERDEJO, José Luis Y SANCHO REBULLIDA, Francisco, Elementos de Derecho Civil. V. Derecho de Sucesiones, Librería Bosch, 1988 p.79: CAPILLA, Francisco, LOPEZ, Angel Maria, ROCA, Encarna, VALPUESTA, M ${ }^{\mathrm{a}}$ Rosario, MONTÉS; Vicente Luis, Derecho de Sucesiones, Tirant lo Blanch, 1992, p.65; LLEDO YAGÜE, Francisco, Derecho de Sucesiones. Vol I.. Universidad de Deusto,1989, p.113, LASARTE ALVAREZ, Carlos, Principios de Derecho civil. T. VII. Derecho de Sucesiones, Marcial Pons, 2005, p. 43.

9 ALBALADEJO GARCIA, Manuel, $O b$, cit. p.205

10 Vid. Entre otros: MANRESA Y NAVARRO, José Maria, Ob. cit. p. 80; PÉREZ DE VARGAS MUÑOZ, José , La indignidad sucesoria en el Código civil español, pp.2527.

11 VALVERDE Y VALVERDE, Calixto, Ob. cit. p.444. 
De este mismo parecer es también la jurisprudencia. La ya mencionada sentencia del Tribunal Supremo de 11 de febrero de 1946, afirma que el artículo 756 del Código civil, recogiendo el sentido tradicional de nuestro Derecho, enraizado a su vez en el Derecho romano, fijó los casos en que el heredero deja de serlo por haber incurrido en causas que moral y legalmente le inhabilitan para entrar en posesión de la herencia.

El instituto de la indignidad sucesoria suscita múltiples y variadas cuestiones. No todas ellas empero pueden ser abordadas, por razones obvias, en los exiguos límites de este trabajo contraído al análisis de una de sus causas. Es menester, sin embargo, hacer una excepción en la cuestión relativa al carácter constitutivo o no de la sentencia que declara la indignidad para suceder ${ }^{12}$. A juicio de HERNÁNDEZ GIL ${ }^{13}$, para que una persona sea declarada indigna a tal efecto " no es suficiente la comisión de la acciones que enumera el artículo 756; se requiere que una sentencia inimpugnable así lo reconozca». De esta opinión participa igualmente VALLET DE GOYTISOLO ${ }^{14}$ al afirmar que en nuestro Código civil «las causa de indignidad han de ser siempre objeto de prueba y declaración judicial correspondiente» para tener eficacia excluyente. Lo que implica otorgar naturaleza constitutiva a la resolución judicial que así lo declara. ALBALADEJO ${ }^{15}$, en cambio, no comparte esta postura; para este autor, « la indignidad no exige necesariamente una sentencia que la disponga, sino que solo, cuando se discuta, requiere de una sentencia que decida que realmente se es indigno por haberse cometido en verdad hecho indigno.» Resultan sin embargo difícilmente imaginables eventuales hipótesis de indignad para suceder que no precisen de la mediación judicial.

La redacción originaria dada en 1889 al artículo 756 del Código civil se mantuvo incólume ${ }^{16}$ hasta el año 1978 en que la Ley $22 / 78$, de

12 Vid. ALBALADEJO GARCIA, Manuel, Ob. cit. pp.198-205.

13 HERNÁNDEZ GIL, Felix, La indignidad sucesoria: naturaleza jurídica declaración judicial y efectos, Revista de Derecho Privado, 1961, p. 478.

14 VALLET DE GOYTISOLO, Juan, Limitaciones de Derecho sucesorio a la facultad de disponer. T.I. Las legítimas. Instituto Nacional de Estudios Jurídicos, 1974, p. 654.

15 ALBALADEJO GARCIA, Manuel, $O b$. cit. p.203. Trata sobre este tema en las pp.201-205.

16 En su primera redacción el artículo 756 rezaba así : «Son incapaces de suceder por causa de indignidad:

1. Los padres que abandonaren a sus hijos y prostituyeran a sus hijas o atentaren a su pudor.

2. El que fuere condenado en juicio por haber atentado contra la vida del testador, de su cónyuge, descendientes o ascendientes. Sí el ofensor fuere heredero forzoso, perderá su derecho a la legitima. 
26 de mayo, de Despenalización del Adulterio y del Amancebamiento introdujo algunos cambios de diversa significación y alcance. Desapareció, obviamente, la causa quinta, al haber quedado destipificada la conducta base, esto es, la condena en juicio por adulterio con la mujer del testador, de la que traía origen ${ }^{17}$. Y en cuanto a la causa

3. El que hubiese acusado al testador de delito al que la ley señale pena aflictiva, cuando la acusación sea declarada calumniosa

4. ${ }^{\circ} \mathrm{El}$ heredero mayor de edad que, sabedor de la muerte violenta del testador, no la hubiese denunciado dentro de un mes a la justicia, cuando ésta no hubiera procedido ya de oficio. Cesará esta prohibición en los casos en que, según la ley, no hay obligación de acusar.

5. El condenado en juicio por adulterio con la mujer del testador.

6. El que, con amenaza, fraude o violencia, obligare al testador a hacer testamento o a cambiarlo.

$7^{\circ}$ El que por iguales medios impidiere a otro hacer testamento, o revocar el que tuviera hecho, o suplantare, ocultare o alterare otro posterior."

Sobre la causa $4^{\circ}$, puede verse HERNÁNDEZ GIL, Felix, La obligación del sucesor de denunciar la muerte violenta del causant,. Estudios de Derecho Civil en Honor del Prof. Castán Tobeñas, T II. Ediciones Universidad de Navarra. pp. 227-257. Y en cuanto a la causa $6^{\text {a }}$; EL MISMO: Indignidad sucesoria con causa en el artículo 756.6 inciso último del Código civil: falsificar, destruir u ocultar el testamento del causante, La Ley, 1993.2, pp.918-930.

17 Pasando a ser causa de desheredación incluida, por la propia Ley 22/1978, como inciso final del artículo 852 del Código civil, con la siguiente redacción: « Asimismo es justa causa para desheredar haber cometido adulterio con el cónyuge del testador.» Desaparece así la anterior discriminación al sustituir ,certeramente, la expresión " adulterio con la mujer del testador» por la de " adulterio con el cónyuge del testador». Posteriormente la Ley 11/1990, de 15 de octubre, sobre reforma del Código civil, en aplicación del principio de no discriminación por razón sexo, suprimió el inciso final del citado artículo 852. En opinión de FERRANDIS: "Al suprimir el inciso final del artículo 852 no se ha eliminado una discriminación, por la sencilla razón de allí no había discriminación alguna. La expresión cónyuge del testador comprendía tanto a la mujer del testador como al marido de la testadora. Hay que descartar, pues, esta posible explicación ya que, además de ingenua, sería incongruente con la solución adoptada, que no ha consistido en expresar el mismo supuesto en términos amplios y no discriminatorios, sino en la radical supresión del adulterio como causa de desheredación. Resulta, pues , bastante sorprendente la formulación de la regla que comentamos dentro de una ley cuya finalidad se pretende cifrar en un principio de no discriminación. (...) A estas consecuencias que sin duda hay que calificar como muy graves, se llega como resultado del criterio del legislador de 1990, criterio que se cifra en estimar que el adulterio no es conducta a la que deba atribuirse entidad suficiente como para incluirla entre las causas de desheredación. La Ley de 1978 dejó el adulterio desprovisto de sanción penal, pero no lo consideró civilmente irrelevante, como lo demuestra el que dicha Ley añadiera al artículo 852 del Código civil el inciso ( ahora suprimido ). La Ley de 1978 se manifestó tolerante con el adulterio; ahora la Ley de 1990 impone a la persona ofendida la obligación de ser tolerante con quien le ofendió tan gravemente». Vid. FERRANDIS VILELLA, José, Desheredación y adulterio, Boletín del Ilustre Colegio de Abogados de Madrid, $\mathrm{N}^{\circ}$ 6, 1991, pp.11 y 12. 
tercera, ${ }^{18}$ se dispuso que la expresión "pena aflictiva» quedara sustituida por la de «pena no inferior a la de presidio o prisión mayor». Es llamativo y revelador de la incuria y desidia legislativa con que en ocasiones se actúa que hubieran de pasar cincuenta años para que el legislador se percatase de que no existían penas aflictivas en el ordenamiento penal español, pues éstas habían sido sustituidas ya desde el Código penal de 1928 por la de penas graves. No se crea, sin embargo, que hoy en día el defecto se ha remediado. La referida modificación sigue siendo inoperante por ausencia, otra vez, del presupuesto penal que le da vida. El vigente texto punitivo (LO 10/1995, de 23 de noviembre) no contempla la distinción entre presidio y prisión, ni establece distingo alguno en cuanto a esta última. La pena de prisión oscila entre un mínimo de seis meses y un máximo de veinte años, pudiendo alcanzar excepcionalmente los cuarenta años. Se impone pues, consecuentemente, una actuación legislativa que solvente el problema ${ }^{19}$.

Como consecuencia del desarrollo normativo del principio de no discriminación por razón de sexo, la Ley 11/1990, de 15 de octubre suprimió de la causa primera del artículo la dual referencia a hijos e hijas, dispensándoles a todos ellos el mismo tratamiento ${ }^{20}$.

${ }^{18}$ Cuyo artículo $3.3^{\circ}$ preceptuaba: «En el número 3 del artículo 756 se sustituye la expresión 'pena aflictiva' por la de 'pena no inferior a la de presidio o prisión mayor'."

19 La expresión penas aflictivas aparece por vez primera en el Código penal de 1848, se mantuvo en la posterior reforma de 1850 y, así mismo, en el Código de 1870. Estaban previstas para los delitos graves, en tanto que las correccionales y las leves lo estaban para los delitos menos graves y las faltas respectivamente. El Código penal de la Dictadura del General Primo de Rivera sustituyó, en el año 1928, dicha terminología por la de penas graves, menos graves y leves, pero la mantuvo vinculada también, al igual que sus antecesores, a la tripartición de las infracciones penales. Los Códigos penales de 1932 y de1944, apartándose de la tradición, siguieron un sistema bimembre de clasificación de las infracciones penales en delitos y faltas, según que estuvieran castigadas con penas graves o leves. Volviéndose en el Código penal de 1995 al sistema del Código penal de 1928, con notable variación, claro está, de su contenido.

20 Vid. Sobre esta causa HERNÁNDEZ GIL, Felix, La indignidad por incumplimiento de deberes legales, Revista de Derecho Privado, 1965, pp.109-121. Como señala GUILARTE ZAPATERO, Vicente, Comentarios a las reformas del Código Civil, ( Coordinador R. Bercovitz ) Edit. Tecnos, pp.617 - 618 : "El nuevo texto, pues, somete ahora a idéntico régimen la conducta determinante de la indignidad para suceder de los padres con independencia del sexo del hijo sobre el que se proyecte aquélla. Pero, además y al margen de la finalidad especifica de la Ley, es decir, borrar cualquier desigualdad en aplicación del principio de no discriminación por razón de sexo, parece que se elimina también el atentado al pudor como causa de indignidad y se contempla, además de la prostitución de los hijos, su corrupción.

Por cuanto se refiere al apuntado ejercicio propio de la modificación, procede observar que también en el precepto presente ésta es más formal que sustantiva, ya 


\section{ANÁLISIS ESTRUCTURAL DE LA CAUSA SÉPTIMA DEL ARTÍCULO 756 DEL CÓDIGOCIVIL}

Más recientemente, la Ley $41 / 2003$, de 18 de noviembre ${ }^{21}$, de protección patrimonial de las personas con discapacidad, modificadora del Código Civil, de la Ley de Enjuiciamiento Civil y de la Normativa Tributaria, introdujo bajo el número $7^{\circ}$, una nueva causa de indignidad para suceder que reclama nuestra atención y que dice así: "Tratándose de una persona con discapacidad, las personas con derecho a la herencia que no le hubieren prestado las atenciones debidas, entendiendo por tales las reguladas en los artículos 142 y 146 del Código Civil", son incapaces para suceder por causa de indignidad. Ello «supone haber elevado a tal categoría la negativa a la prestación de alimentos cuando ésta se refiera a la sucesión de un discapacitado ${ }^{22}$. Pasando así el Código Civil a contar nuevamente con el mismo número de causas que tuviera originariamente y que perdió a raíz de la reforma del año 1978, si bien no con el mismo contenido. Lo que hace que el catálogo de causas de nuestro Código sea uno de los más amplios, si no el que más ${ }^{23}$ entre los de nuestro entorno, cuando la tendencia es a reducir su número. Como advierte BARASSI ${ }^{24}$, los

que, generalmente se venia interpretando que en el espíritu del texto originario se comprendía, no solo el abandono de los hijos, sino asimismo el de las hijas, y no obstante la literalidad de la norma se estimaba igualmente como causa de indignidad la prostitución de los hijos. Y ello al margen y con anterioridad a la vigencia del artículo 14 de la Constitución.

Respecto del otro extremo del cambio legislativo, puede ser dudoso si, en efecto, eliminada del nuevo precepto la referencia del atentado al pudor, tal supresión implica que la expresada conducta desaparece como causa de indignidad. A favor de tal criterio cabe aducir, no sólo el silencio legal, sino también, como precisa la STS de 11 de febrero de 1946, que los supuestos dudosos han de decidirse a favor del presunto indigno, ya que in dubio pro benignitate habetur. Sin embargo, la solución contraria puede encontrar justificación en que, como observa ALBALADEJO (Discurso pronunciado en el acto de investidura Doctor Honoris Causa. Granada 1991. p. 41), « la conducta del padre intentando la corrupción del hijo, evidente atentado a su pudor, es reprobable al margen de que éste resista o no al atentado.»

21 Vid. La tramitación parlamentaria en lo relativo a esta causa en: PÉREZ DE VARGAS MUÑOZ, José, La causa de indignidad para suceder del artículo 756-7 ${ }^{\circ}$ del Código civil, en el libro Protección jurídica y patrimonial de los discapacitados, Escola Galega de Administración Pública, Xornadas y Seminarios, Xunta de Galicia, 2005, pp.237-244.

${ }^{22}$ ROCA GUILLAMÓN, Juan, La protección de los mayores en el Derecho Civil, Discurso leído en la Real Academia de Legislación y Jurisprudencia de Murcia, 22 de octubre de 2004, p.91.

${ }^{23}$ CASTÁN TOBEÑAS, José, Derecho Civil Español, Común y foral. T. VI. Derecho de Sucesiones. Vol. Segundo, Edit. Reus, 1975, p.46.

${ }_{24}$ BARASSI, Lodovico, Le sucessióni per causa di morte, Edit. Giuffre, Milán, 1947, p.55. 
sistemas construidos en torno a la indignidad sucesoria oscilan entre el máximo del Código civil español, con sus nuevamente siete causas de indignidad y el mínimo del Código napoleónico. Lo que a juicio de ALBALADEJO ${ }^{25}$, y nuestro, no es acertado; hubiera sido preferible una enumeración más reducida de causas, pero con un contenido más genérico que conjurase el riesgo de dejar fuera del campo de aplicación del precepto alguna causa que tal vez pudiera ser más grave que las que en él se contemplan.

\section{II.1. ANTECEDENTES}

El nuevo supuesto de indignidad sucesoria cuenta con escasos antecedentes en nuestro derecho patrio, con la salvedad del Proyecto de 1851, cuyo artículo 617 establecía que: "Son indignos y como tales no pueden adquirir por testamento: $5^{\circ} \mathrm{El}$ pariente del difunto, que, hallándose éste loco o demente y abandonado, no cuidó de recogerle o hacerle recoger en un establecimiento público ${ }^{26}$. Pero no mereció la atención de los redactores del Anteproyecto de 1882, ni, por supuesto, del legislador de 1889. Entre dicho antecedente y la nueva causa séptima hay ciertas analogías y diferencias notables, las más acusadas estriban en el diferente contenido de la ayuda, patrimonial en un caso, y de atención y de cuidado en el otro, cuya omisión es causa de indignidad para suceder.

Tampoco los Códigos de nuestro entorno conocen una causa análoga. No obstante, un precedente remoto lo encontramos en el Allgemeines Landrecht für die preussischen Staaten ( Derecho territorial general de los Estados Prusianos) de 1794, cuyo artículo 762 declaraba indignos a los padres y parientes que no se cuidaron de dar alimentos a aquél de cuya herencia se trata ${ }^{27}$. Este precepto era más amplio que la actual causa $7^{\mathrm{a}}$ de artículo 756 del Código civil, al no requerir que el alimentista padeciera ningún tipo de enfermedad, incapacitación o discapacidad.

25 ALBALADEJO GARCIA, Manuel, $O b$, cit, p.208.

${ }^{26}$ En el Proyecto de 1851 el causante había de ser loco o demente, motivo ( la locura o demencia, aunque se tuvieran intervalos lúcidos) que posteriormente fue acogido por el Código civil de 1889 , como causa de sujeción a tutela en el artículo 200.2. ${ }^{\circ}$, hasta que la Ley 13/1983, de 24 de octubre, de reforma del Código civil en materia de tutela, modificó este precepto estableciendo, también en el artículo 200, las causas de incapacitación judicial, que son las enfermedades o deficiencias persistentes de carácter físico o psíquico que impidan a la persona gobernarse por si mismo.

27 GARCIA GOYENA, Florencio, Concordancias. Motivos y Comentarios del Código civil español. T.II, Imprenta de la Sociedad Tipográfica - Editorial, 1852, p. 65. 
En lo concerniente al Derecho foral, ni la Ley 40/1991, de 30 de diciembre, Código de Sucesiones por Causa de Muerte en el Derecho civil de Cataluña, cuyo artículo 11 determina quien es indigno de suceder ${ }^{28}$; ni la Ley 1/1999, de 24 de febrero, de Sucesiones por Causa de Muerte, de Aragón, cuyo artículo 13 regula las causas de indignidad $^{29}$, estableciendo quienes son incapaces de suceder por causa de indignidad, acogen un motivo igual o similar, pese a la similitud de

28 Artículo 11: «Es indigno para suceder: $1^{\circ}$. El que ha sido condenado mediante sentencia firme en juicio penal por haber matado o intentado matar voluntariamente al causante, a su cónyuge o a un descendiente o ascendiente de aquél.

$2^{\circ}$. El que ha sido condenado mediante sentencia firme en juicio penal por calumnias al causante por haberlo acusado de un delito para el cual la Ley señale una pena no inferior a la prisión mayor.

$3^{\circ}$. El que ha testificado en juicio contra el causante, al cual sea imputado un delito para el cual la Ley señale una pena no inferior a la prisión mayor, si su testimonio ha sido declarado falso mediante sentencia firme en juicio penal.

$4^{\circ}$. El que de forma ilegal ha inducido al causante el otorgamiento, la revocación o la modificación de un testamento o se lo ha impedido; el que, conociendo estos hechos ha hecho uso de los mismos; el que ha destruido, alterado o ocultado el testamento, o quienes han sido condenados en sentencia firme por dejar de pagar durante tres meses consecutivos o seis alternos cualquier tipo de prestación económica establecida a favor de su cónyuge o sus hijos en convenio judicialmente aprobado o resolución judicial en los supuestos de separación legal, divorcio o nulidad matrimonial.

$5^{\circ}$. Los padres que han abandonado a sus hijos causantes o han atentado contra su dignidad y que por estos hechos han sido condenados por sentencia.»

29 Artículo 13: «Son incapaces de suceder por causa de indignidad:

a) Los padres que abandonaren, prostituyeren o corrompieren a sus descendientes.

b) El que fuere condenado por haber atentado contra la vida del causante, de su cónyuge, descendientes o ascendientes, contra la vida del fiduciario o contra la vida de otro llamado a la herencia cuya muerte favorezca en la sucesión al indigno.

c) El que fuere condenado a pena de inhabilitación especial para el ejercicio de los derechos de patria potestad o autoridad familiar, tutela, guarda o acogimiento familiar, en las sucesiones de loas personas sobre las que versaré la pena y sus descendientes.

d) El que fuere condenado por acusación o denuncia falsa contra el causante o el fiduciario, en relación con un delito para el cual la Ley señale una pena grave.

e) El heredero mayor de edad que, sabedor de la muerte violenta de su causante, no la hubiese denunciado dentro de un mes a la justicia, cuando no hubiera procedido ya de oficio.

f) El que, con amenaza, fraude o violencia, obligare al causante o al fiduciario a otorgar, revocar o modificar las disposiciones sucesorias.

g) El que por iguales medios impidiera a otro otorgar pacto sucesorio, testamento o acto de ejecución de la fiducia, o revocar o modificar los que tuviese hechos, o suplantare, ocultare o alterare otros posteriores.» 
las otras causas con las del Derecho civil común ${ }^{30}$. Las restantes Compilaciones forales no regulan esta materia. Pero tanto en un caso como en otro se plantea el problema de la posible aplicabilidad de la causa séptima, con carácter supletorio, en los territorios de Derecho foral, de conformidad con la regla general del artículo 13.2 del Código civil ${ }^{31}$. La Exposición de Motivos de la Ley 41/2003, se pronuncia a favor de la supletoriedad de la Ley en general y, por consiguiente, y de manera implícita, también a favor de la causa que nos ocupa. Solución ésta por la cual me inclino. De otra opinión, DIAZ $A L A B A R T^{32}$, para la que " esta reforma de Derecho sucesorio no afecta a las personas sometidas a los Derechos civiles de origen histórico, pues éstas continuarán rigiéndose en esta materia por sus propias normas sucesorias».

\section{II.2. AMBITO DE APLICACIÓN PERSONAL}

Para que pueda entrar en juego la previsión del artículo 756 es preciso que se trate de persona discapacitada y ello tanto por el tenor literal de la causa en cuestión que lo exige expresamente - «sucesión de una persona con discapacidad»-, como por la finalidad de la propia Ley 41/2003 y las continuas referencias que al respecto se hacen en la Exposición de Motivos $^{33}$. Matizándose sin embargo en

30 Según la Exposición de Motivos de la Ley 41/2003: " La regulación contenida en esta Ley se entiende sin perjuicio de las disposiciones que pudieran haberse aprobado en las comunidades autónomas con derecho civil propio, las cuales tienen aplicación preferente de acuerdo con el artículo $149.1 .8^{\mathrm{a}}$ de la Constitución española y los diferentes estatutos de autonomía, siéndoles de aplicación esta Ley con carácter supletorio, conforme a la regla general contenida en el artículo 13.2 del Código civil». Además, hay que tener en cuenta la disposición final primera, que bajo la rúbrica de título competencial, establece: "Esta Ley se dicta al amparo de lo dispuesto en el artículo 149.1.6 ${ }^{\mathrm{a}} .8^{\mathrm{a}}$ y $14^{\mathrm{a}}$ de la Constitución".

31 Preceptúa el artículo 13 del Código civil: «1. Las disposiciones de este Título Preliminar en cuanto determinan los efectos de las leyes y las reglas generales para su aplicación, así como las del Título IV, Libro I, con excepción de las normas de este último relativas al régimen económico matrimonial, tendrán aplicación general y directa en toda España.

2. En lo demás, y con pleno respeto a los derechos especiales o forales de las provincias o territorios en que estén vigentes, regirá el Derecho civil como derecho supletorio, en defecto del que lo sea en cada uno de aquellas, según sus normas especiales.»

32 DIAZ ALABART, Silvia, La protección juridica de las personas con discapacidad. (Estudio de la Ley 41/2003, de Protección Patrimonial de personas con discapacidad), Edit. Ibermutuamur. 2004, p.212.

33 Señala la Exposición de Motivos en el apartado I, párrafo segundo: "Hoy constituye una realidad la supervivencia de muchos discapacitados a sus progenitores, 
esta última que: «beneficiarios de este patrimonio pueden ser, exclusivamente, las personas con discapacidad afectadas por unos determinados grados de minusvalía, y ello con independencia de que concurran o no en ellas las causas de incapacitación judicial contempladas en el artículo 200 del Código civil y de que, concurriendo, tales personas hayan sido o no judicialmente incapacitadas ${ }^{34}$."

Por persona discapacitada, a los efectos del artículo $756.7^{\circ}$ del Código civil, hay que entender aquella que cumple lo exigido en el artículo 2.2 de la Ley 41/2003, según el cual: «A los efectos de esta ley únicamente tendrán la consideración de personas con discapacidad: a) Las afectadas por una minusvalía psíquica igual o superior al 33 por ciento. b) Las afectadas por una minusvalía física o sensorial igual o superior al 65 por ciento.» Ello supone, en definitiva, introducir en el Código civil un concepto nuevo, el de persona con discapacidad o discapacitada, que no es lo mismo que persona incapacitada judicialmente, aunque, es cierto, que a veces puede coincidir ambas situaciones en una misma persona.

En la medida en que, como señala la Exposición de Motivos, no toda persona incapacitada judicialmente tendrá por ello la condición

debido a la mejora de asistencia sanitaria y a otros factores, y nuevas formas de discapacidad como las lesiones cerebrales y medulares por accidentes de tráfico, enfermedad de Alzheimer y otras, que hacen aconsejable que la asistencia económica al discapacitado no se haga sólo con cargo al Estado o a la familia, sino con cargo al propio patrimonio que permite garantizar el futuro del minusválido en previsión de otras fuentes para costear los gastos que deben afrontarse». Bien es cierto, empero, que el precepto que estoy comentando nada tiene que ver con el objeto fundamental de esta Ley que es constituir un patrimonio para el discapacitado, pues como se señala en la Exposición de Motivos: «Esta Ley tiene por objeto regular nuevos mecanismos de protección de las personas con discapacidad, centrados en un aspecto especial de esta protección, cual es el patrimonial. Efectivamente uno de los elementos que más repercuten en el bienestar de las personas con discapacidad es la existencia de medios económicos a su disposición, suficientes para atender las específicas necesidades vitales de los mismos.» «De esta forma, — sigue diciendo aquélla- el objeto inmediato de esta Ley es la regulación de una masa patrimonial, al patrimonio especialmente protegido de las personas con discapacidad, la cual queda inmediata y directamente vinculada a la satisfacción de las necesidades vitales de una persona con discapacidad, favoreciendo la constitución de este patrimonio y la aportación a título gratuito de bienes y derechos a la misma." Sin embargo, la Ley 41/2003, modifica también el Código civil, introduciendo pequeños cambios en materia de sucesiones, siendo uno de ellos la inclusión de una nueva causa de indignidad para suceder, con el fin de proteger a la persona discapacitada.

34 Aunque la Exposición de Motivos hace referencia fundamentalmente al patrimonio protegido para personas discapacitadas, que es la piedra angular de la Ley, también aborda ésta otras instituciones jurídicas, como la autotutela, la indignidad sucesoria, la posibilidad de gravar la legítima con una sustitución fideicomisaria, la facultad de mejorar concedida al cónyuge viudo, el contrato de alimentos, etc. 
de discapacitada, será menester dilucidar, en primer término, ambas situaciones y una vez alcanzada la conclusión de que es una persona discapacitada, se procederá a comprobar sí alcanza el grado de minusvalía exigible para que pueda ser declarada legalmente discapacitada. Para su acreditación se necesitará un «certificado expedido reglamentariamente o por resolución judicial firme», artículo 2.3 de la Ley $41 / 2003^{35}$. Otros supuestos distintos quedan fuera de su aplicación, como sucede con aquellas leyes de Comunidades Autónomas (Ley de Atención y Protección de Ancianos del Parlamento de Andalucía, de 7 de julio de 1999) cuyas exigencias sean inferiores a las de la Ley 41/2003.

La no inclusión en la causa séptima de las personas incapacitadas judicialmente la considero desacertada y acaso fuente de problemas, a no ser que se entienda que todo incapacitado judicialmente es al propio tiempo un discapacitado. Pero de no ser así no se alcanza a comprender el distinto tratamiento que se les da a unos y a otros. PEREÑA VICENTE ${ }^{36}$ se cuestiona, sin dar respuesta, si será acaso que se considera de mayor gravedad negar alimentos a un discapacitado que al incapacitado judicialmente.

Otras parcelas del Derecho sucesorio se han visto también afectadas por esta reforma, sí bien únicamente en cuanto a personas incapacitadas judicialmente, o sin mención específica alguna al respecto $^{37}$.

35 En el mismo sentido RUIZ-RICO RUIZ MORÓN, Julia, La reforma del Derecho de sucesiones con motivo de la protección de personas con discapacidad. Actualidad Civil N. ${ }^{\circ}$ 4. Segunda quincena de febrero de 2004. pp.358-359. "No basta pues una deficiencia ( pérdida o anormalidad de una estructura o función psicológica, fisiológica o anatómica ) que repercuta directamente en la capacidad del sujeto de realizar actividades en los términos considerados normales para un ser humano (discapacidad ) y que esa deficiencia, y consiguiente limitación de la capacidad de llevar a cabo actividades, genere una situación desventajosa para el individuo en tanto le impida el desempeño de un rol social que le es propio ( minusvalía ). Es necesario, además, que la valoración de discapacidad alcance el porcentaje que se precisa en la Ley. No importa sin embargo, a estos efectos, que la deficiencia constituya o no causa de incapacitación conforme al artículo 200 del Código civil; y tampoco, caso de serlo, que se haya o no seguido el procedimiento oportuno y obtenido la declaración judicial correspondiente. Mientras que todo incapacitado va a ser persona con discapacidad, no se puede hacer, sin embargo la afirmación inversa; puede ocurrir que la causa de discapacidad no sea causa de incapacitación , o incluso que, siendo la causa de discapacidad causa de incapacitación, no se haya instado el procedimiento judicial correspondiente y no exista sentencia incapacitadora."

36 PEREÑA VICENTE, Montserrat, El Derecho sucesorio como instrumento de protección del discapacitado, La Ley. $\mathrm{N}^{\circ}$ 5957, Miércoles 18 de febrero de 2004, p.1829.

37 El primer caso, se produce con la posibilidad de que la legitima estricta pueda ser gravada con una sustitución fideicomisaria en beneficio de un hijo o descen- 
La nueva causa de indignidad sucesoria no hace acepción de personas por razón de edad, pero es obvio que en la mayoría de los casos será de aplicación a personas de edad avanzada, sobre todo en los supuestos, cada día más frecuentes, de la enfermedad de Alzheimer que expresamente menciona la Exposición de Motivos.

\section{II.3. CLASES DE SUCESIÓN EN LAS QUE SE APLICA}

De manera problemática y reduccionista la Exposición de Motivos de la Ley 41/2003 no duda en proclamar que: «Se configura como causa de indignidad generadora de incapacidad para suceder abintestato el no haber prestado al causante las atenciones debidas durante su vida, entendiendo por tales los alimentos regulados por el Título VII del libro I del Código Civil, y ello aunque los causahabientes no fueran una de las personas obligadas a prestarlos.»

De aceptarse acríticamente el contenido del párrafo transcrito resultaría, por un lado, que quedarían fuera de su ámbito de aplicación los supuestos de sucesión testada, y de otro, que el causahabiente obligado a prestar alimentos no tendrá por qué ser exclusivamente una de las personas que, de conformidad con el artículo 143 del Código civil, están recíprocamente obligados a ello. Lo que no es de recibo, al menos en lo que al primer aspecto se refiere; pues es lo cierto que la nueva causa se inserta dentro de las causas de indignidad sucesoria, que afecta sin distinción alguna a la sucesión testamentaria y a la legitima $^{38}$. Acaso se trate de un lapsus del legislador, solución a la que se recurre en numerosas ocasiones cuando no se encuentra una res-

diente judicialmente incapacitado. Por lo que se ha añadido un tercer párrafo al artículo 808 como consecuencia de ello; también se ha introducido un segundo párrafo en el artículo 813, y modificado la redacción del artículo 782, todos del Código civil.. La Ley 41/2003, ha modificado asimismo el artículo 831 del Código civil que contempla la facultad de mejorar concedida al cónyuge viudo o conviviente supérstite a favor de los hijos o descendientes comunes. Este precepto, sin embargo, no exige que éstos sean discapacitados o hayan sido incapacitados judicialmente.

38 Sobre este punto hay unanimidad en la doctrina. A diferencia de la desheredación que solo afecta a la sucesión testada en virtud de lo preceptuado en el artículo 849, primer inciso del Código civil: «La desheredación solo podrá hacerse en testamento." Podemos señalar entre otros autores a MANRESA Y NAVARRO, José Maria, Ob. cit. p.82; VALVERDE Y VALVERDE, Calixto, Ob. cit. p.443; ALBALADEJO GARCIA, Manuel, $O b$. cit. p. 205; CASTAN TOBEÑAS, José, $O b$. cit. p. 46; LACRUZ BERDEJO, José Luis y SANCHO REBULLIDA, Francisco, Ob. cit, p.79; CAPILLA, Francisco, LOPEZ, Angel $\mathbf{M}^{\mathrm{a}}$, ROCA, Encarna, VALPUESTA, $\mathbf{M}^{\mathrm{a}}$ Rosario, MONTÉS, Vicente Luis, $O b$. cit. p.65; LLEDO YAGUË, Francisco, Ob. cit. p.113; LASARTE ALVAREZ, Carlos, $O b$. cit. p.43. 
puesta más adecuada, pues si su voluntad hubiera sido que solo afectara a la sucesión intestada, lo lógico hubiera sido mencionarlo de forma expresa en el $n^{\circ} 7^{\circ}$ del artículo 756. Sin embargo, se guarda silencio sobre este particular, y al ser un motivo más de indignidad, hay que tener en cuenta las reglas generales de ésta, lo que significa que se aplicará a las dos clases de sucesiones es decir tanto a la sucesión testamentaria como a la sucesión intestada o legítima.

A ello se añade también la circunstancia de que la capacidad para testar se reconoce a todos aquellos, conforme previene el artículo 662 del Código civil, a quienes la ley no se lo prohíbe expresamente. Únicamente están incapacitados al respecto, según el artículo 663, los menores de catorce años y el que habitual o accidentalmente no esté en su sano juicio. En este último supuesto, es decir, como personas carentes de sano juicio podrían considerarse aquellos discapacitados afectados por una minusvalía psíquica igual o superior al 33 por ciento, según lo preceptuado por el artículo 2.2.b) de la Ley 41/2003, y que, además, habitualmente no estuvieran en su sano juicio; porque sí sólo lo estuvieran accidentalmente, habrá que estar a lo dispuesto en el artículo 666 del Código civil que establece que: « Para apreciar la capacidad del testador se atenderá únicamente al estado en que se halle al tiempo de otorgar el testamento". Siendo pues la insanidad o no del testador en ese momento la determinante de su testimentifacio activa.

De lo expuesto resulta que de los discapacitados a que se refiere el artículo 2.2 de la Ley 41/2003, tan sólo son incapaces para testar aquellos cuya discapacidad provenga de una minusvalía psíquica que en el momento de testar impida que estén en su sano juicio. En cambio, sí pueden testar los discapacitados cuya minusvalía psíquica no les prive de su sano juicio, y, por supuesto, quienes lo sean como consecuencia de una minusvalía física o sensorial igual o superior al sesenta y cinco por ciento, que para nada afecta al cabal juicio del testador. Dado, pues, que la regla es la no privación de la facultad de testar a los discapacitados, no se alcanza a comprender por qué la Exposición de Motivos circunscribió esta causa de indignidad a la sucesión intestada.

RUIZ-RICO ${ }^{39}$ da la siguiente respuesta, que: "La persona con discapacidad pueda testar, y que efectivamente lo haga, tiene importancia porque la institución de heredero o el nombramiento de legatarios efectuados a favor de quien ha incurrido en la conducta indigna de negarle las atenciones debidas, constituye remisión de la

39 RUIZ-RICO RUIZ MORÓN, Julia, Ob. cit. p. 361. 
indignidad por vía de rehabilitación tácita, siempre que el testador conociera la causa de indignidad al tiempo del otorgamiento (artículo 757). Por esta razón, seguramente, la Exposición de Motivos de la Ley comentada afirma que, el no haber prestado al causante las atenciones debidas, se configura como causa de indignidad generadora de incapacidad para suceder abintestato.» Opinión respetable, pero que no comparto, porque podría deducirse que en todos aquellos supuestos en que el testador conociendo la causa de indignidad instituye heredero o legatario a una persona presuntamente indigna, originando con ello una rehabilitación, no tiene por qué significar que las causas de indignidad se configuren exclusivamente como generadoras de incapacidad para suceder abintestato.

En consecuencia, entiendo que si las causas de indignidad sucesoria despliegan su efectividad en ambas clases de sucesión, no hay razón alguna, salvo la extemporánea mención de la Exposición de Motivos, para que la nueva causa contraiga su aplicación exclusivamente a la sucesión abintestato ${ }^{40}$.

\section{II.4. FALTA DE PRESTACIÓN AL CAUSANTE POR PARTE DEL CAUSAHABIENTE DE LAS ATENCIONES DEBIDAS}

Para que el causahabiente sea declarado indigno de suceder al causante discapacitado es necesario que no le haya prestado a éste la atención debida, entendiendo por tal la regulada en los artículos 142 y 146 del Código civil, esto es, no haber cumplido con la prestación de alimentos a que viene obligado, en proporción al caudal o medios de quien los da y a las necesidades de quien los recibe. Único supuesto de esta Ley afectante al Derecho sucesorio en el que está prevista «una medida que afecta a la herencia del discapacitado y no a una herencia a la que es llamado éste ${ }^{41} . "$

Lo que haya de entenderse por alimentos lo determina el artículo 142 del Código civil ${ }^{42}$. Comprende tanto el sustento material, inte-

${ }^{40}$ La misma posición es defendida, también, por PÉREZ DE VARGAS MUÑOZ, José, La causa de indignidad para suceder del artículo 756-7 ${ }^{\circ}$ del Código civil, pp.259-264.

41 PEREÑA VICENTE, Montserrat, Ob. cit. p.1829.

42 El artículo 142 del Código civil señala: «Se entiende por alimentos todo lo que es indispensable para el sustento, habitación, vestido y asistencia médica. Los alimentos comprenden también la educación e instrucción del alimentista mientras sea menor de edad y aún después, cuando no haya terminado su educación por causa que no le sea imputable. Entre los alimentos se incluirán los gastos de embarazo y parto, en cuanto no sean cubiertos de otro modo". 
grado por el mero hecho o acto de dar de comer, de beber, cuanto el alojamiento, el vestido, la educación e instrucción del alimentista, y la atención sanitaria; tiene, por consiguiente, un acusado contenido patrimonial.

La redacción del artículo 142 del Código civil, fruto de la Ley 11/1981, de 13 de mayo, de modificación del Código civil en materia de Filiación, Patria potestad y Régimen Económico del Matrimonio, suprimió el ultimo inciso del párrafo primero que vinculaba la prestación alimenticia a «la posición social de la familia». Sin embargo, no falta algún autor que estima «que ello no debe entenderse realmente eliminado, ya que es elemento a tener en cuenta, sea o no, como por algunos se pretende, elemento clasista, dado que nos parece evidente para la fijación de los mismos tener en cuenta además de los medios económicos con que el alimentante pueda contar, el medio o ambiente social en que se haya desarrollado la vida familiar del mismo y del alimentista, al menos en la medida de lo posible ${ }^{43}$." Por el contrario DELGADO ECHEVERRIA ${ }^{44}$, de manera a mi entender más acertada y conforme con la reforma de la Ley 11/1981, considera que «estas necesidades han de apreciarse en relación con la persona concreta ( aunque desde 1981, sin tener en cuenta la posición social suya y de su familia), en el ámbito de lo preciso para el sustento, habitación, vestido, asistencia médica y educación. Necesidades, se entiende, a las que él no puede subvenir por sí, mediante el gasto de sus bienes patrimoniales y el acrecimiento de éstos por su trabajo. Al haber desaparecido - en la reforma de 1981- el módulo de la posición social de la familia, parece que el alimentista habrá de gastar todo su patrimonio, incluso cuando la venta de los bienes sólo sea posible en condiciones desventajosas, antes de recibir alimentos. En cuanto a la capacidad de trabajo, si el artículo $152.3^{\circ}$ dispone que cese el derecho cuando el alimentista pueda ejercer un oficio, profesión o industria, es lógico que no llegue a nacer sí existe tal posibilidad».

Por otro lado «las características propias de la obligación alimenticia la hacen incompatible con la naturaleza de la típica y pura obligación patrimonial. Pero ello no es obstáculo para que el contenido de la obligación alimenticia sea estrictamente patrimonial, es decir, económico. Son valores económicos, son prestaciones de con-

43 MARTIN GRANIZO Y FERNÁNDEZ, Mariano, Código Civil. Doctrina y Jurisprudencia. T. III. ( Dirigidos por J.L. Albácar ) Edit. Trivium, 1991, p.914.

${ }^{44}$ DELGADo ECHEVERRIA, Jesús, Comentario del Código Civil. T.I. Ministerio de Justicia, 1991, pp.531-532. 
tenido patrimonial las que debe realizar el alimentista; alimentos, vestido, habitación, etc. Y se deben prestar, precisamente, porque el alimentario carece de patrimonio, se encuentra en estado de necesidad y está necesitado de valores económicos. Por paradójico que parezca, la obligación alimenticia tiene una prestación con un contenido más acusadamente patrimonial que la mayoría de las obligaciones patrimoniales. En este orden de ideas y por lo mismo que la obligación alimenticia es de contenido patrimonial, está ausente de ella toda obligación de carácter personal como sería el cuidado de la persona del alimentado según la tesis de CICU. El cuidado de la persona del alimentado tiene lugar cuando la obligación alimenticia no es autónoma, sino vinculada a un deber familiar, es decir, cuando los alimentos se prestan como efecto personal del matrimonio (deber de los cónyuges de socorrerse mutuamente) o en el cumplimiento del poder-deber de patria potestad (art. 155) hoy artículo 154. Pero ya hemos visto como estas situaciones no constituyen propiamente una obligación legal de alimentos ${ }^{45}$."

Como el presente trabajo se contrae únicamente al estudio de la causa séptima de indignidad para suceder y con exclusiva referencia a las personas mayores, he de señalar que a éstas no les resulta aplicable lo dispuesto en el párrafo segundo y tercero del artículo 142. Cabe, sin embargo, imaginar hipótesis en las que sea de aplicación, aunque excepcionalmente, respecto de causantes mayores a los que en su día, durante su minoría de edad, se les negó la prestación alimenticia que dichos párrafos contemplan.

Al causante discapacitado, mayor de edad, se le tiene que haber negado lo necesario para el sustento, habitación, vestido o asistencia médica. No obstante, creo que en la causa séptima del artículo 756, también, debería haberse incluido el cuidado y atención personal del discapacitado, a pesar de que la obligación alimenticia, como se ha señalado, tenga un carácter netamente patrimonial ${ }^{46}$.

45 BELTRAN DE HEREDIA Y ONIS, Pablo, Comentarios al Código civil y Compilaciones forales. T. III, Vol.2', (Dirigidos por M. Albaladejo), Edit. Edersa. 1982, p.1920.

46 Como señala MARTÍN GRANIZO Y FERNÁNDEZ, Mariano, ( Ob. cit. p.939) la doctrina se ha planteado una serie de preguntas en relación al artículo 146, entre las que merece destacar " hasta que punto el alimentante puede ser compelido a la realización de actividades laborales o profesionales más amplias e incluso distintas de las que ordinariamente desarrolla si con las actuales no puede satisfacer adecuadamente su obligación alimenticia; incluso también se plantea la cuestión de sí en estos casos, y no queriendo el primeramente obligado a satisfacerlos conforme a la relación de deudores alimentarios del artículo 143, deberá desarrollar el trabajo o la actividad que 


\section{II.5. ¿SOBREPASAN LAS PERSONAS OBLIGADAS A PRESTAR ALIMENTOS A LOS ALIMENTANTES MENCIONADOS EN EL ARTÍ́CULO 143 DEL CÓDIGO CIVIL?}

Como quiera que el incapaz para suceder, por causa de indignidad, lo es precisamente por «no haber prestado las atenciones debidas» al causante durante su vida, o sea, por no haber cumplido con la obligación alimenticia que le era exigida, es preciso determinar con carácter previo quienes están legalmente obligados a ello; pues sólo el obligado puede incumplir el deber prestacional que le incumbe incurriendo así en causa de indignidad. La determinación, sin embargo, de quiénes vengan obligado a ellos no resulta en absoluto sencilla. Pues la Ley que da vida a esta nueva causa no sólo guarda silencio sobre ello, obligando al intérprete a realizar una tarea hermenéutica de integración de la norma, sino que complicándolo todavía más pretende circunscribir aquélla, como ha quedado dicho, únicamente al ámbito de la sucesión intestada y, al propio tiempo, extenderla a personas no comprendidas en el artículo 143 del Código civil. Así lo proclama expresamente la Exposición de Motivos de la Ley 41/2003 al decir que: «Se configura como causa de indignidad generadora de incapacidad para suceder abintestato el no haber prestado al causante las atenciones debidas durante su vida, entendiendo por tales los alimentos regulados por el título VI del libro I del Código civil, y ello aunque el causahabiente no fuera una de las personas obligadas a prestarlos ${ }^{47}$ ».

Según he tratado de razonar anteriormente, la causa séptima del artículo 756 comprende tanto la sucesión testada como la intestada; $\mathrm{y}$, en consecuencia, las personas a las cuales se les va a declarar indignas son aquellas con derecho a la herencia que no han prestado las atenciones debidas a la persona discapacitada. Por ello hay que distinguir a estos efectos entre ambas clases de sucesiones.

venia desempeñando cuando este abandono o cesación tenga por objeto el no satisfacerlos o se traslada la obligación al alimentante del siguiente grado en esa escala de deudores alimenticios. Las opiniones sobre estos aspectos no son coincidentes. Así, y por lo que al primero se refiere, predomina la tesis de quien debe prestarlos no puede ser obligado a procurarse o a desarrollar alguna actividad o profesión que le permita contribuir a su obligación alimentista. En cuanto a la posibilidad de que el débito alimentario pueda en estos casos trasladarse al obligado en segundo lugar, la posición más generalizada en nuestra doctrina se inclina a admitirlo. A su vez es de indicar que, dada la redacción del artículo 146, son los Tribunales quienes tienen a su cargo resolver, con sujeción a su prudente arbitrio, uno y otro aspecto de la cuestión: cantidad o medios del alimentante, necesidades del alimentista. Entre otras sentencias del Tribunal Supremo cabe destacar: 7 de octubre y 2 de diciembre de 1970, 16 de noviembre de 1978,9 y 30 de enero de 1986 y 14 de marzo de 1988."

47 La cursiva es mía. 
En cuanto a la sucesión testamentaria, son legitimarios los hijos y descendientes, los padres y ascendientes y el cónyuge viudo que al morir su consorte no se hallase separado de éste judicialmente o de hecho, a tenor de los artículo 807 y 834 del Código civil. Pero junto a éstos, también, pueden ser herederos o legatarios cualesquiera personas a quienes el testador haya instituido como tales en la parte de libre disposición, por lo que el elenco de personas se amplía notablemente. Posición que también mantiene PÉREZ DE VARGAS ${ }^{48}$ «la nueva causa del artículo 756 C.c. no solo afectará a las personas 'con derecho a la herencia' del discapacitado, sino también a los que hubieren sido llamadas a la sucesión de éste como legatarios.» Respecto a la sucesión ab intestato, son herederos forzosos las personas que integran la línea recta descendente y ascendente, así como el cónyuge viudo no separado judicialmente o de hecho, y los parientes colaterales hasta el cuarto grado, aunque los hermanos e hijos de hermanos suceden con preferencia a los demás colaterales, artículos 930 y siguientes del Código civil.

Antes de proseguir con el análisis emprendido es preciso examinar si la declaración de indignidad afecta o no a la legítima de los herederos forzosos, de manera que también el legitimario declarado indigno quedaría en tal caso privado de ésta. Esta cuestión ha sido resuelta afirmativamente en la doctrina actual después de que un sector minoritario ${ }^{49}$, basándose en la explicita referencia hecha en el $\mathrm{n}^{\circ}$ 2 del artículo $756^{50}$ a la pérdida del derecho a la legítima si el ofensor fuere heredero forzoso y en la interpretación restrictiva de toda norma sancionadora, sostuviera que tal consecuencia sólo tenía lugar en el supuesto de la causa segunda. En cambio, hoy en día la mejor doc-

48 PÉREZ DE VARGAS MUÑOZ, José, La causa de indignidad para suceder del artículo 756-7 ${ }^{\circ}$ del Código civil, p.259.

49 Entre otros, VALVERDE Y VALVERDE, Calixto, Ob. cit. p. 448, para quien, «como quiera que el Código civil, sólo en la causa segunda de indignidad y no en las seis restantes ,dice que privará de la legítima, es para nosotros indudable, que habiendo de interpretarse el Código restrictivamente ,las causas de indignidad, a excepción de la segunda, no producen el efecto de privar de la legítima a los herederos forzosos; su indignidad cuando hay causa, se refiere a la parte voluntaria de la institución. Ahora bien; no hay que olvidar que las causa $1^{\mathrm{a}}, 3^{\mathrm{a}}, 5^{\mathrm{a}}$ y $6^{\mathrm{a}}$ del artículo 756 son causas de desheredación, que utilizadas por el testador pueden privar de la legítima; más las causas $4^{\mathrm{a}}$ y $7^{\mathrm{a}}$, ni aún ese efecto pueden producir, al no considerarlas el legislador como causas de desheredación». MANRESA Y NAVARRO, José Maria, Ob. cit. p.82.

50 Artículo 756: «Son incapaces de suceder por causa de indignidad: $2^{\circ}$ El que fuere condenado en juicio por haber atentado contra la vida del testador, de su cónyuge, descendientes o ascendientes.

Sí el ofensor fuere heredero forzoso, perderá su derecho a legítima». 
trina ${ }^{51}$ sostiene la posición - que comparto— de que todas las causas de indignidad son de aplicación a los herederos forzosos, sin que exista razón válida alguna para limitar sus efectos a la parte de libre disposición y excluir de ellos a la legítima. En este sentido, afirma ALBALADEJO ${ }^{52}$ que «es innegable que la gravedad de la conducta del indigno contra el causante merece que se le prive de toda sucesión respecto a él, así que ante ello debe ceder hasta el derecho a la sucesión forzosa que la legítima representa, pues en tanto que sucesor forzoso, el legitimario, ha de reunir las condiciones de aptitud para heredar al causante, que, por definición, faltan a los indignos, que, como dice al principio el artículo (756) son incapaces para suceder por causa de indignidad. Pensar otra cosa no es coherente. No cabe negar que el espíritu que preside la presente materia (por mucho que ni lo diga expresamente la ley, ni que frases que sí diga, permitan sobre su pura literalidad montar argumentos en contra) es que el indigno quede sin ningún derecho sucesorio frente al causante, salvo que éste lo rehabilite, y eso conduce incluso a negarle la legítima. Por último, tal como pudiera usarse para apoyar la postura que rechazo, que sólo para la causa $2^{\mathrm{a}}$ de indignidad dice el artículo que pierda el indigno su derecho a la legítima, cabe usar a favor de la que defiendo que: $1^{\circ}$, el artículo 761 da por sentado que todo indigno pierde tal derecho, puesto que, por cualquiera de las causas de indignidad, es un excluido de la herencia por incapacidad, y para caso de tal exclusión prevé el artículo 761 que sus hijos y descendientes adquieren su derecho a la legítima, lo que no tendría sentido sí el no lo perdiese; $2^{\circ}$ y el 713, que verdaderamente recoge caso de indignidad, y aunque no dice explícitamente que el indigno pierda la legítima, sin embargo, es su espíritu al hablar de perderá todo derecho a la herencia».

Por su parte, el Tribunal Supremo, en sentencia de 28 de febrero de 1947, asume este criterio predominante declarando que las causas de indignidad " privan a quien en ellas incurra del derecho a suceder al agraviado, aunque sea heredero forzoso, porque la incapacidad si es relativa con relación al de cuius, es absoluta por lo que afecta a su patrimonio, no sólo porque así cabe inferirlo de su naturaleza y fundamento, dada la trascendencia social de los hechos que la originan,

51 Cabe citar, entre otros, a CASTÁN TOBEÑAS, José, Ob. cit. p. 49; VALLET DE GOYTISOLO, Juan, Ob. cit. p.84; LACRUZ BERDEJO, José Luis y SANCHO REBULLIDA, Francisco, $O b$. cit. p. 81; CAPILLA, Francisco, LOPEZ, Angel Maria, ROCA, Encarna, VALPUESTA, $\mathbf{M}^{\mathrm{a}}$ Rosario, MONTÉS, Vicente Luis, Ob. cit. p.68; LLEDÓ YAGÜE, Francisco, Ob. cit. p.115; LASARTE ALVAREZ, Carlos, Ob. cit. p. 44; JORDANO FRAGA, Francisco, Ob. cit. pp.51 y 52.

52 ALBALADEJO GARCIA, Manuel, Ob. cit. pp. 207 y 208. 
sino también del contenido del artículo 761 del Código y aun del mismo principio de inviolabilidad de la legítima, que no puede prevalecer por inconciliable con la sucesión cuando el heredo se halla incurso en tan graves motivos de incapacidad». En la misma línea, la sentencia del Tribunal Supremo de 6 de diciembre de 1963 considera de obligada observancia el régimen de legítimas, salvo el caso de indignidad o de justa desheredación.

Es de observar, tras esta necesaria digresión sobre la legítima, que a efectos de la nueva causa de indignidad, el grupo de personas con derecho a la herencia es superior al de personas obligadas a darse alimentos, ya que éstas, según el artículo 143 del Código civil, quedan circunscritas al cónyuge, ascendientes, descendientes, y hermanos, estando obligados éstos únicamente a los auxilios necesarios para la vida, cuando lo necesiten por cualquier causa que no sea imputable al alimentista y se extenderán en su caso a lo que precisen para su educación.

El que vaya a ser heredero tiene obligación de dar alimentos a la persona discapacitada, y ello independientemente de que no venga obligado en virtud del artículo 143 del Código civil, esto es, incluso cuando el causahabiente no fuera una de las personas llamadas ex lege a prestarlos, como recuerda la Exposición de Motivos. Acertadamente ha puesto el dedo en la llaga DÍAZ ALABART ${ }^{53}$ al señalar que «sí se trata de personas que no tienen dicho deber de alimentos, $¿$ de donde sale que esa atenciones sean debidas?, o dicho de otra forma ¿ por qué se deben? ¿ Simplemente porque lo afirma ahora el artículo 756.7 del Código civil? Pues sí como parece, es así, el nuevo párrafo debería haber tenido una mejor redacción, porque no queda claro quienes son los que deben prestar estas atenciones y hasta qué limites han de hacerlo. No es lógico que el hecho de la discapacidad de una persona, sin más, de lugar a que cualquiera que pueda ser su sucesor tenga una obligación de igual entidad que quienes están obligados legalmente a prestárselos, sólo que en este segundo caso la obligación es exigible jurídicamente y en el primero no, pero que en ambos casos se sanciona igualmente con la indignidad y la consiguiente incapacidad sucesoria. (...) También es subrayable que en algún caso el artículo 756.7 del Código civil es más duro con el alimentante que la propia obligación legal de alimentos entre parientes. En éstas, el artículo 143 in fine hace más suave la obligación de prestarlos entre hermanos, pues en este caso limita las alimentos a

53 DÍAZ ALABART, Silvia, La protección juridica de las personas con discapacidad. Edit. Ibermutuamur, 2004, p. 214. 
los necesarios para la vida, y en su caso, a los de educación. Mientras tanto el artículo 756.7 del Código civil no establece ningún tipo de distinción y remite al artículo 142 del Código civil que los dispone amplios por igual para todos los casos".

La nueva causa extiende la sanción de la indignidad sucesoria tanto a los alimentantes genuinos ex artículo 143, como a quienes no siéndolos propiamente, sin embargo vienen obligados a prestarlos por mor del artículo $756.7^{\circ}$. A partir de ahora, toda persona que tenga derecho a la herencia, con independencia de que sea legitimario, heredero forzoso, así como cualquiera otra que hubiera sido llamada a la sucesión como heredero legatario, adquiere por este sólo hecho la condición de alimentante del causante discapacitado.

Los descendientes, ascendientes, cónyuge viudo, y parientes colaterales hasta el cuarto grado, a pesar de que los parientes en tercer y cuarto grado no tienen obligación de alimentos, son presuntos herederos por su relación de parentesco con el causante discapacitado en la sucesión intestada, y parece que el Código parte de la presuposición de que son sabedores de que si no le prestan las atenciones debidas pueden ser indignos para sucederle. Las demás personas, en cambio, no tienen porque saber que pueden heredar, a no ser que el testador se lo haya comunicado - y eso cuando pudiera hacerlo por no carecer de capacidad de obrarque sería el único supuesto en el que estaría obligado a ello y no podría alegar ignorancia. En los demás casos de sucesión testamentaria, en los que no existe una previa y cognoscible obligación legal de dar alimentos y que, por tanto, nadie los reclama, no parece posible alcanzar, en términos de la lógica de lo razonable, la consecuencia de que quien así se comporta resulta indigno para suceder. Por ello coincido con DÍAZ ALABART ${ }^{54}$ en que "si no hay obligación legal de alimentos, entramos en un supuesto que desde luego no puede calificarse a priori de grave, puesto que no tiene sentido tachar de tal una conducta a la que no se está obligado legalmente. Más, aún, puede parecer hasta desproporcionado hablar en este caso de conducta indigna». Pero no puedo compartir la conclusión de que "es evidente que esta ha sido la opción del legislador ${ }^{55}$ », pues ello equivaldría a consagrar una obligación de

54 DIAZ ALABART, Silvia, La protección juridica de las personas con discapacidad, Edit. Ibermutuamur, 2004, pp. 212 y 213.

55 DIAZ ALABART, Silvia, La protección jurídica de las personas con discapacidad, Edit. Ibermutuamur, 2004, pp.212 y 213. 
imposible cumplimiento, por desconocimiento de su existencia, y sabido es que ad imposibilia nemo tenetur. Consecuentemente, entiendo que, en todo caso, el alimentante debe tener conocimiento de la obligación que le incumbe y a sabiendas de ello dejar de cumplirla, con independencia de que se trate de sucesión testada o intestada. Lo contrario supondría sancionar con la privación del derecho a la herencia un mero incumplimiento objetivo cuya existencia el así sancionado ignoraba. Postura distinta es mantenida por PÉREZ DE VARGAS ${ }^{56}$ que señala: «Debe quedar claro, por tanto, que para escapar a la indignidad nadie podrá esgrimir que no era persona directamente obligada a prestar alimentos al discapacitado porque en el orden de prelación de los alimentantes había otras personas obligadas a hacerlo preferentemente, conforme al artículo 144 del Código civil.»

En la realidad el problema carecerá, por lo general, de trascendencia práctica, pero no por ello deja de evidenciar el escaso rigor con el que actúa el legislativo desde hace algún tiempo. A este respecto debe tenerse en cuenta: $1^{\circ}$. Que las aportaciones de bienes o derechos efectuadas por un tercero al patrimonio protegido de la persona discapacitada, quedan sujetas al destino que el aportante establezca; pudiendo éste determinar que, una vez extinguido aquél por fallecimiento del beneficiario, reviertan al aportante o a sus herederos o darles el destino lícito que estime conveniente, artículo 4.3 de la Ley 41/203 y Exposición de Motivos. Por lo que si el tercero opta porque los hereden sus causahabientes, quedan fuera del patrimonio protegido del beneficiario y no podrá disponer de ellos mortis causa.

$2^{\circ}$. Que salvo la hipótesis en que el patrimonio protegido haya sido constituido por el propio beneficiario, por disponer de medios económicos suficientes para ello, bien porque haya sido ya discapacitado o prevea que vaya a serlo en un futuro más o menos próximo; en los restantes casos provendrá de las aportaciones de otras personas, precisamente porque carece de bienes para ello y, por tanto, susceptibles de integrar su herencia.

$3^{\circ}$. Que si es necesario que otros le presten alimentos, ello significa que (salvo casos extraordinarios: premios de lotería, indemnización como consecuencia de un accidente de tráfico o supuesto análogo etc., acaecidos con posterioridad a la necesidad de aquéllos) su caudal hereditario será escaso o nulo.

56 PÉREZ DE VARGAS MUÑOZ, José, La causa de indignidad para suceder del artículo $756-7^{\circ}$ del Código civil, p.258. 
$4^{\circ}$. Que, a diferencia, del régimen de prelación que establece el artículo 144 del Código civil para la satisfacción de la prestación alimenticia por parte de quienes vienen legalmente obligados a ello, la nueva regulación nada dice. Entiendo, sin embargo, que ha de estarse a lo dispuesto en el precitado artículo cuando resulte de aplicación y que en los restantes casos deberá seguirse el orden sucesorio; si bien esta última solución no deje de resultar insatisfactoria en ocasiones.

De lo expuesto resulta, pues, que las posibilidades prácticas de aplicación de la nueva causa de indignidad sucesoria son harto escasas, más allá del circulo de los alimentantes ex artículo 143 del Código civil. A ello es de añadir, además, que el causante puede rehabilitar al indigno, conforme al artículo 757 del Código civil ${ }^{57}$. En la sucesión testamentaria, si el testador con discapacidad conocía al tiempo de otorgar testamento la existencia de la causa $\mathrm{n}^{\circ} 7$ y no obstante lo instituye heredero, ello significa que lo rehabilita. Si conociendo la causa después de haber hecho testamento, le perdona, también queda rehabilitado; pero el perdón ha de constar en documento público. Mas si habiendo incurrido en tal causa no le nombra heredero o legatario, ello supone la inhabilitación para suceder por causa de indignidad del causahabiente ${ }^{58}$.

A la pregunta de si en la sucesión intestada se puede admitir la rehabilitación tácita, DÍAZ ALABART responde: «Cabe presumir que, si el causante conocía la causa de indignidad, y no testó a favor de otros para impedir que la herencia llegará al indigno, cosa que de otro modo sucedería irremisiblemente al ser pariente con derecho a suceder ab intestato, podría tratarse de una rehabilitación tácita. La prueba de que la indignidad era conocida por el causante corresponde al indigno. Sí éste no pudo probar que el causante la conocía no habrá rehabilitación ${ }^{59} . »$

Sí a pesar de la indignidad, el indigno toma posesión de la herencia, la persona que hubiera sucedido de no haberlo hecho el indigno ostenta un interés legítimo y puede reclamársela en el plazo de

57 Artículo 757: "Las causas de indignidad dejan de surtir efecto sí el testador las conocía al tiempo de hacer testamento, o sí habiéndolas sabido después las remitiere en documento público".

58 DIAZ ALABART, Silvia, Comentario del Código Civil. T. I, Ministerio de Justicia, 1991 , p.1865, sostiene que " el causante puede levantar la sanción que la indignidad supone para el indigno. Se puede decir que aquella es una pena privada, y la ley permite que el interesado decida sí el indigno le hereda o no.»

59 DIAZ ALABART, Silvia, La protección jurídica de las personas con discapacidad, Edit. Ibermutuamur, 2004, p.212. 
cinco años; transcurridos los cuales el incapaz queda en posesión de la herencia o legado, a tenor del artículo 762 del Código civil.

Finalmente, sí el excluido de la herencia por incapacidad fuera hijo o descendiente del testador y tuviere hijos o descendientes, adquirirán éstos su derecho a la legítima, según el artículo 761 . A sensu contrario ello quiere decir que respecto de las restantes personas declaradas indignas no cabe el derecho de representación.

\section{III. ¿ESTA CAUSA DE INDIGNIDAD ES TAMBIÉN CAUSA DE DESHEREDACIÓN?}

Entiendo que la respuesta ha de ser negativa. En primer lugar, porque el legislador no remite esta causa de indignidad a los preceptos reguladores de las causas de desheredación, como hubiera resultado procedente. En segundo lugar, porque los artículos 853,854 y 855 donde se establecen las causas de desheredación de los hijos y descendientes, de los padres y ascendientes y del cónyuge, incluyen la de haber negado sin motivo legitimo los alimentos al padre $o$ ascendiente que le deshereda (artículo 853.1); ; sus hijos o descendientes sin motivo legítimo (artículo $854.2^{\mathrm{a}}$ ); a los hijos o al otro cónyuge (artículo $855.3^{\circ}$ ). El instituto de la desheredación cuenta con su propia y más amplia regulación, no limitada en modo alguno a la situación de discapacidad de quien deshereda, como sucede con la nueva causa de indignidad; por lo que cualquier testador puede desheredar al legitimario o legitimarios que le hayan negado alimentos, sin motivo legítimo en los dos primeros supuestos, y siempre que así lo exprese en el testamento ${ }^{60}$.

60 La misma postura es defendida por JORDANO FRAGA, Francisco, Ob. cit. pp. 27 y 28: «en lo que respecta a la causa de indignidad sucesoria definida en el $n^{\circ} 7$ del artículo 756 del Código civil, podría pensarse que el referirse dicha causa a la sucesión de una persona con discapacidad (éste es el causante ofendido), y al ser ésta, normalmente persona desprovista de capacidad para testar (y, por ende, desheredar), lo que justifica que en esta caso la causa de indignidad se convierta al mismo tiempo en de justa desheredación. Y así, también aquí, la ley no habrá operado la conversión en un caso donde, desde los requisitos legalmente exigidos a la justa desheredación, dicha conversión no resultaba (la mayoría de las veces) posible. Pero me inclino a pensar que en este caso las razones de la no conversión legal son de otra especie. El mismo hecho que el número 7 del artículo 756 del Código civil define ahora como causa de indignidad (operante en la sucesión del causante discapacitado) encaja, sin dificultad, en las causas de desheredación que definen, respectivamente, los artículos 853-1 ${ }^{\mathrm{a}}, 854-2^{\mathrm{a}}$ y $855-3^{\mathrm{a}}$ del Código civil y, por tanto, con fundamento en ese mismo hecho, y al amparo de las indicadas normas el discapacitado que pueda otorgar testamento válido (hipótesis que, pese a la discapacidad que le afecta, también puede darse) podrá desheredar al legitimario suyo que lo cometa». 


\section{CONCLUSIÓN}

La causa séptima del artículo 756 pretende proteger a la persona discapacitada con el fin de que cualquier heredero que no le haya dispensado las atenciones debidas, entendiendo por tales la prestación alimenticia que establece el artículo 142 del Código civil, en proporción al caudal o medios del alimentante y a las necesidades del alimentista, sea indigno de sucederle.

Ahora bien, como esta causa de indignidad para suceder parte del presupuesto de que la persona discapacitada carece de patrimonio con el que subvenir a sus necesidades y de ahí la necesidad de que un tercero le preste alimentos, ello supondrá que en muchos ocasiones carezca de significación práctica alguna.

La dificultades pragmáticas de funcionamiento y de articulación de la misma subsisten incluso si la causa hubiera incluido también, primándolo, el aspecto psíquico, la falta de cariño, atención y cuidado a la que en tantas ocasiones se ven avocadas las personas mayores, máxime cuando se trata de discapacitados, cuyos últimos días transcurren en la más absoluta soledad y el olvido de quienes van a ser sus herederos. Bien pudo, pues, el legislador haber ampliado el radio de acción de esta causa de indignidad dando cabida en su seno a la desafección de los causahabientes, introduciendo un componente personal en la obligación prestacional que ahora no tiene. Al modo, salvadas las distancias, como hiciera el Proyecto de Código civil de 1850 (artículo $617-5^{\circ}$ ), que consideraba indigno de adquirir por testamento al pariente del difunto, que, hallándose éste loco o demente y abandonado, no cuidó de recogerle o hacerle recoger en un establecimiento público. Pero soy consciente de que, amén de no ser fácil su articulación jurídica, la falta o escasez de patrimonio con el que motivar la actuación en tal sentido del tercero no por ello dejaría de existir. Mas cuando no fuese así, esto es, cuando la persona discapacitada dispusiera de bienes, no se alcanza a comprender por qué la desafección no podría llevar aparejada consigo también tacha de indignidad prevista hoy en día tan sólo para la ausencia de prestaciones de contenido económico. 